\title{
A new species of Rhytidhysteron (Ascomycota: Patellariaceae) from Colombia, with a provisional working key to known species in the world
}

\author{
Edier Soto-Medina ${ }^{1, *}$, Robert Lücking² \\ ${ }^{1}$ Departamento de Biología, Facultad de Ciencias Naturales, Universidad del Valle, Cali, Colombia \\ ${ }^{2}$ Botanischer Garten und Botanisches Museum, Berlin, Germany
}

\begin{abstract}
We describe a new species, Rhytidhysteron columbiense Soto-Medina \& Lücking, from Colombia. It is a saprobic species found on decaying branches in montane rain forest remnants, characterized by boat-shaped ascomata up to 3 $\mathrm{mm}$ long and $1.8 \mathrm{~mm}$ wide, with brown-black disc and yellowish-green pruina, perpendicularly striate margins, and by 3 -septate, ellipsoid to fusiform, red-brown ascospores $38-52 \times 13-18 \mu \mathrm{m}$ in size. The new species differs from all other species in the genus by the yellowish-green pruina on the margins of the ascomata and from $R$. rufulum s.lat. also in the larger ascospores, whereas $R$. brasiliense has similarly long ascospores, but differs in their broader width and their pigmentation, as they remain light brown at maturity. A provisional working key to known species of the genus in the world is provided based on literature data. (C) 2017. Acad. Colomb. Cienc. Ex. Fis. Nat.
\end{abstract}

Key words: Rhytidhysteron; Ascospore; Pruina; Colombia.

Una nueva especie de Rhytidhysteron (Ascomycota:Patellariaceae) de Colombia, con una clave provisional para las especies conocidas en el mundo

\begin{abstract}
Resumen
Se describe la nueva especie Rhytidhysteron columbiense Soto-Medina \& Lücking para Colombia. Es una especie saprobia encontrada sobre ramas en descomposición en remanentes de bosque montano lluvioso; se caracteriza por ascomas en forma de canoa de cerca de $3 \mathrm{~mm}$ de longitud y 1,8 $\mathrm{mm}$ de ancho, con disco marrón negruzco y pruina verde amarillosa, márgenes estriados perpendicularmente, y tres esporas septadas, elipsoides a fusiformes, marrón rojizas, de 38-52 × 13-18 $\mu \mathrm{m}$ de tamaño. Esta nueva especie difiere de las otras del género por la pruina verde amarillosa sobre los márgenes del ascoma, y de $R$. rufulum s.lat. por las esporas más grandes, mientras que $R$. brasiliense tiene las esporas grandes, pero difiere por sus ascosporas más anchas y por su pigmentación, que es de color pardo claro en la madurez. Se agrega una clave provisional para las especies del género en el mundo con base en datos de la literatura. (C) 2017. Acad. Colomb. Cienc. Ex. Fis. Nat.
\end{abstract}

Palabras clave: Rhytidhysteron; Ascospora; Pruina; Colombia.

\section{Introduction}

Rhytidhysteron is a small genus of about 20 species typified by R. brasiliense Speg. (Spegazzini, 1881; SilvaHanlin \& Hanlin, 1999). The genus includes saprobic to weakly pathogenic fungi growing on woody plants, wellcharacterized by its rather large, conspicuous ascomata, which are usually elongate and boat-shaped and feature a prominent, perpendicularly striate margin, in combination with pigmented, sparsely septate to submuriform ascospores. The genus appears to have a subcosmopolitan distribution, with species described from all continents (Spegazzini, 1881; Rosatto, 1996; Hsieh, et al., 1997; Tanaka \& Hosoya, 2006; Murillo, et al., 2009; Méndez-Mayboca, et al., 2010; Almeida, et al., 2014; Yacharoen, et al., 2015; Doilom, et al., 2016; Thambugala, et al., 2016). Rhytidhysteron has received attention for its secondary chemistry (Murillo, et al., 2009; Pudhom \& Teerawatananond, 2014; Pudhom, et al., 2014; Chokpaiboon, et al., 2016) and the human-pathogenic properties detected in some species (Spatafora, et al., 1995; Wipf, et al., 2004; Chowdhary, et al., 2008; Mahajan, et al., 2014; Mishra, et al., 2014; Chander, et al., 2016).

The genus was revised by Samuels \& Müller (1980), who reduced the 11 names listed in the genus at the time to only two species, namely $R$. rufulum (Spreng.) Speg. (with $R$. brasiliense as synonym) and $R$. hysterinum (Dufour) Samuels \& E. Müll. However, it was later shown that

\footnotetext{
*Correspondencia:

Edier Alberto Soto Medina, ediersot@gmail.com

Recibido: 16 de octubre de 2016

Aceptado: 15 de marzo de 2017
} 
their conclusions were based on superficial observations or ignorance of the character of the corresponding type specimens, including ascoma morphology and ascospore size (Kutorga \& Hawksworth, 1997; Thambugala, et al., 2016). Further studies including molecular and chemical data indicated that Rhytidhysteron is more diverse than assumed and that $R$. rufulum is species complex (Boehm, et al., 2009; Murillo, et al., 2009; Yacharoen, et al., 2015; Doilom, et al., 2016; Thambugala, et al., 2016). As a result, about 20 species are currently recognized, but based on the rather local studies by Murillo, et al. (2009) in Costa Rica and Doilom, et al. (2016) and Thambugala, et al. (2016) in Thailand, many more species are to be expected in this genus. Here we describe a new species discovered in Colombia, which even without the support of molecular data differs from all other accepted species, featuring large ascomata and the longest ascospores known in the genus and a unique ascoma morphology, with yellowish-greenpruinose margins.

\section{Materials and methods}

Material was collected during a field trip to Cerro San Antonio in a mountainous area of Cali, as part of the III Meeting of the Colombian Group of Lichenologists (GCOL). This locality, also known as Cerro de la Horqueta, is $22 \mathrm{~km}$ from the city of Cali, at an altitude of 2000-2200 m, with the coordinates $76^{\circ} 58^{\prime} \mathrm{N}$ and $03^{\circ} 29^{\prime} \mathrm{W}$. The Cerro San Antonio is characterized by a rather well-preserved montane forest and has been the subject of several studies of flora (Alvarez, et al., 1987).

We took pictures of the fungus both in the field and the laboratory with a Nikon D3100 and a Canon PowerShot SX160 digital camera. Ascomata sections were mounted for microscopic identification in a water medium. Measurements of ascomata, hamathecium, exciple, ascospores and asci were made in water. Photographs of the hamathecium, exciple, and ascospores, were taken with an Olympus microscope and Canon PowerShot SX160 camera. The material was deposited in the herbarium of the universidad del Valle.

\section{Results}

Rhytidhysteron columbiense Soto-Medina \& Lücking, sp. nov. Figure 1. Index Fungorum IF552900

Diagnosis. A new species similar to Rhytidhysteron brasiliense, particularly in ascospore size, but differing in the larger ascomata with yellowish-green pruina on the margin.

Type. COLOMBIA. Valle del Cauca: Cali, Cerro de San Antonio (Horqueta); 76 $58^{\prime} 14^{\prime \prime} \mathrm{N}, 5^{\circ} 44^{\prime} 55^{\prime \prime} \mathrm{W}, 2000-2200$ $\mathrm{m}$; on fallen, decaying woody branch; April 2013, E. A. SotoMedina \& R. Lücking s.n (holotype CUVC 62421).

Etymology. The species epithet, columbiense, refers to the country where the material was collected.

Description. Saprobic on decaying branches in montane rain forest remnants. Ascomata 1.5-(2.66)-3.0 mm long, 1.2-
(1.59)-1.8 mm wide, $0.6-0.7 \mathrm{~mm}$ high $(\mathrm{n}=14)$, hysterothecial, boat-shaped, crowded to aggregate, superficial, brown-black but with distinct, yellowish-green pruina on the margins, with exposed, lenticular to irregular, brown-black disc when wet, folded along the margins when dry and forming an elongate slit, perpendicularly striate. Exciple 60-90 $\mu \mathrm{m}$ wide $(\mathrm{n}=$ 8), composed of dark brown to black, thick-walled cells of textura angularis. Hamathecium comprised of dense, septate pseudoparaphyses, branched and forming a dark epithecium above the asci, fused and slightly swollen at the apex and enclosed in a gelatinous matrix. Asci 175-190 $\times 14-18 \mu \mathrm{m}$, 6-8-spored, bitunicate, cylindrical, with short, furcate pedicel, rounded at the apex, with distinct ocular chamber. Ascospores $38-(43.5)-52 \times 13-(14.7)-18 \mu \mathrm{m}(\mathrm{n}=17)$, uniseriate, slightly overlapping, hyaline when immature, becoming reddish-brown when mature, ellipsoidal to fusiform, rounded to slightly pointed at both ends, (1-)3-septate, with smooth wall. Asexual morph: not observed.

\section{Discussion}

Except for medical and chemical studies or studies relating to economically important crops (Pena, 1967; Restrepo, 1970; Chaparro, et al., 2009; Vega, et al., 2010), ascomycetous fungi have received little attention in Colombia, with only a few reports of conspicuous families such as Cordycipitaceae, Nectriaceae, Sarcoscyphaceae, and Xylariaceae. This is actually the first report of the genus Rhytidhysteron and the family Patellariaceae for Colombia (Vazco \& Franco Molano, 2014), and it is striking that this first find resulted in the discovery of a species new to science.

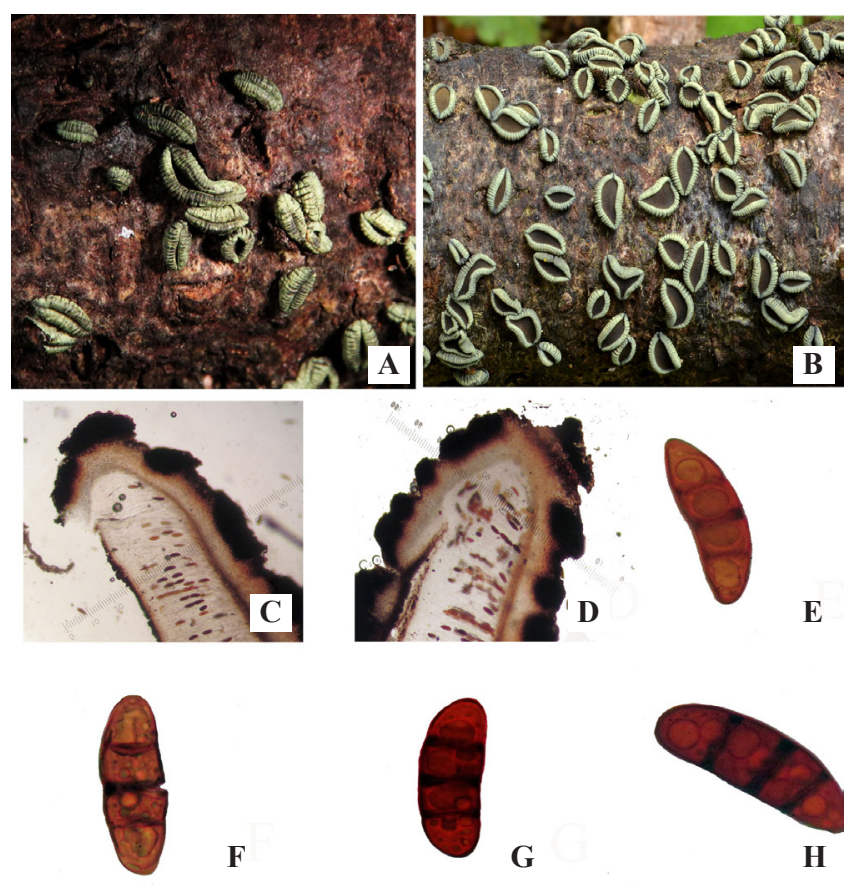

Figure 1. Dry Ascomata of Rhytidhysteron columbiense A, appearance of hysterothecia on host $\mathbf{B}$, Hamathecium detail and striations $\mathbf{C}$, asci with ascospores $\mathbf{D}$, ascospores $\mathbf{E}-\mathbf{H}$. 
Rhytidhysteron columbiense agrees with most other species in the genus in the more or less boat-shaped, sessile ascomata with a perpendicularly striate margin. This combination of characters is also found in $R$. rufulum, which has recently been shown to be a collective taxon including several species (Murillo, et al., 2009; Thambugala, et al., 2016). However, $R$. columbiense is not another segregate of the $R$. rufulum aggregate, since it differs from the latter in important features. All species or lineages currently distinguished in the $R$. rufulum aggregate have ascomata with non-pruinose, black margins and either black or colored (redbrown to orange) disc, quite different from the yellow-green pruinose margins and non-pruinose, brown-black disc in $R$. columbiense. The only exception is material of $R$. rufulum s.lat. reported from Japan and Taiwan (Hsieh, et al., 1997; Tanaka \& Hosoya, 2006), which exhibits chocolate-brown discs combined with a grey margin [http://chawantake.sakura. ne.jp/data/Rhytidhysteron_rufulum.html; http://old.taibif. tw/en/namecode/140476] and almost certainly represents an undescribed taxon. In addition, ascospores in species of the $R$. rufulum aggregate are 20-37 $\times 7-14 \mu \mathrm{m}$ in size, whereas in $R$. columbiense they are much larger, 38-52 $\times 13-18 \mu \mathrm{m}$. Thus far, only two species of Rhytidhysteron are known with ascospores of a similar, large size: $R$. brasiliense has entirely black, non-pruinose ascomata and its ascospores are slightly broader and lack the characteristic red tinge of those of $R$. columbiense (Spegazzini, 1881; Kutorga \& Hawksworth, 1997; Thambugala, et al., 2016); $R$ dissimile (P. Karst.) Magnes also features black, non-pruinose ascomata and has predominantly 5-septate ascospores that remain yellowish.

Even without molecular data, this finding highlights the urgent need for a deeper study of microfungi in Colombia, which are supposed to be much more diverse than macrofungi, but their potential richness in the country has barely been addressed by taxonomic study and hence their potential importance and uses cannot be currently assessed. In addition, this result supports the notion that microfungi are in important source for unrecognized species richness, and the genus Rhytidhysteron appears to be a prime example how such diversity has not previously been recognized, with potentially dozens of species waiting to be discovered. This is of particular interest considering the potential chemical and medical implications of fungi in this genus (Spatafora, et al., 1995; Wipf, et al., 2004; Chowdhary, et al., 2008; Murillo, et al., 2009; Mahajan, et al., 2014; Mishra, et al., 2014; Pudhom \& Teerawatananond, 2014; Pudhom, et al., 2014; Chander, et al., 2016; Chokpaiboon, et al., 2016).

Provisional working key to known species of Rhytidhysteron in the world. In the following key, all currently listed names in the genus Rhytidhysteron are keyed out, with the exception of $R$. minor (Cooke) A. Pande [comb. inval.], which likely represents a species of Opegrapha, and $R$. viride Speg. (Spegazzini 1881), which appears to be an unrelated lichenicolous fungus; the taxonomic affinities of $R$. beccarianum (Ces.) Bat. \& Valle are also uncertain although it is included below. The key provides access to the taxa thus far assigned to Rhytidhysteron but does not conform a taxonomic revision.

1a. Ascospores submuriform, with 3-5 transverse and 0-3 longitudinal septa per segment; ascomata with red-brown disc and black margins; type: U.S.A. ....................... $\boldsymbol{R}$. opuntiae (J.G. Br.) M.E. Barr (Brown, 1953; Barr, 1990)

1b. Ascospores transversely (1-)3(-5)-septate; ascomata variable

2a. Ascospores partially 5-septate, 30-46 × 12-20 $\mu \mathrm{m}$; ascomata black with black, striate margins; type: Finland R. dissimile (P. Karst.) Magnes (Karsten, 1866; Magnes, 1997)

2b. Ascospores at most 3-septate, variously sized; ascomata variable

3a. Ascospores consistently 1-septate, 20-28 × 12-15 $\mu \mathrm{m}$; ascomata (red-)brown with brown margins; type: France R. hysterinum (Dufour)

Samuels \& E. Müll. (Samuels \& Müller, 1980)

4a. Ascospores 38-52 × 13-21 $\mu \mathrm{m}$.......................... 5

4b. Ascospores (12-)19-37 × (5-)8-14 $\mu \mathrm{m}$............... 6

5a. Ascomata brown-black with yellow-green, striate margins; ascospores red-brown; type: Colombia

R. columbiense Soto-Medina \& Lücking (this paper)

5b. Ascospores black with black, striate margins; ascospores brown; type: Brazil R. brasiliense Speg. (Spegazzini, 1881)

6a. Ascospores 12-15 × 5-6 $\mu \mathrm{m}$; ascomata brown with olive margins; type: Sri Lanka R. beccarianum

(Ces.) Bat. \& Valle (Batista \& Maia, 1964)

6b. Ascospores 19-37 × 7-14 $\mu \mathrm{m}$ 7

7a. Ascoma disc (brown-)black or grey with (brown-) black margin

7b. Ascoma disc yellow- to red-brown or cinnabar-red with (brown-)black margin 13 Notes. If ascoma disc chocolate-brown with grey margins, see Hsieh, et al. (1997) and Tanaka \& Hosoya (2006), which represents an undescribed species.

8a. Ascoma disc slate grey to dark grey .................... 9

8b. Ascoma disc (brown-)black ............................. 10

9a. Ascoma margins striate; ascospores 25-30 × 12-14 $\mu \mathrm{m}$, about 2 times as long as broad; type: U.S.A. ............. $\boldsymbol{R}$. fuscum (Ellis \& Everh.) J.L. Bezerra \& Kimbr. (Ellis, 1889; Ellis \& Everhart, 1892; Bezerra \& Kimbrough, 1979)

9b. Ascoma margins smooth; ascospores 30-32 × 10-12 $\mu \mathrm{m}$, about 3 times as long as broad; type: India ............. $\boldsymbol{R}$. indicum (Anahosur) M.P. Sharma \& K.S. Thind (Anahosur, 1971; Sharma \& Rawla, 1986)

10a. Ascospores 30-37 × 10-14 $\mu \mathrm{m}$; ascoma margins striate 11

10b. Ascospores $20-31 \times 9-12 \mu \mathrm{m}$; ascoma margins variable

11a. Ascospores with reddish tinge; ascomata up to $2 \mathrm{~mm}$ long; type: Indonesia (Java) ...................... R. javanicum Penz. \& Sacc. (Penzig \& Saccardo, 1897) 
11b. Ascospores lacking reddish tinge; ascomata up to $4 \mathrm{~mm}$ long; type: Paraguay R. guaraniticum Speg. (Spegazzini, 1888)

Notes. Rhytidhysteron clade II from Costa Rica in the study of Murillo, et al. (2009) appears to belong to this taxon; it agrees in ascoma morphology and ascospore size.

12a. Ascomata margins striate; ascospores brown; type: U.S.A. R. prosopidis Peck (Peck, 1894)

12b. Ascoma margins smooth; ascospores yellowish brown; type: Thailand R. thailandicum Thambug. \& K.D. Hyde (Thambugala, et al., 2016)

13a. Ascoma margin striate; ascoma disc orange- to redbrown ( $R$. rufulum complex) 14

13b. Ascoma margin smooth; ascoma disc yellow-brown or orange to cinnabar-red without brown tinge 17

14a. Ascospores 23-24 × 8-9 $\mu \mathrm{m}$; material: Costa Rica $\boldsymbol{R}$. clade IV (Murillo, et al., 2009)

Notes. Rhytidhysteron clade IV from Costa Rica in the study of Murillo, et al. (2009) was considered to represent genuine $R$. rufulum but the ascospores are too small for that species; instead, clade III fits $R$. rufulum well (see below). If disc cinnabar-red, compare $R$. quercinum (see below).

14b. Ascospores 25-36 ×8-13 $\mu \mathrm{m}$. 15

15a. Ascospores 25-27 × 10-12 $\mu \mathrm{m}$; ascospores dark brown; type: Australia .... R. scortechinii Sacc. \& Berl. (Saccardo \& Berlese, 1885)

15b. Ascospores 28-36 ×9-13 $\mu \mathrm{m}$; ascospores (reddish-) brown

16a. Ascoma disc orange-brown; ascospores brown; type: Paraguay R. discolor (Speg.) Speg.

(Spegazzini, 1880, 1919)

16b. Ascoma disc red-brown; ascospores reddish brown; type: Puerto Rico R. rufulum (Spreng.) Speg.

\section{(Spengel, 1820; Spegazzini, 1921)}

Notes. Rhytidhysteron clade III from Costa Rica in the study of Murillo, et al. (2009) seems to represent genuine $R$. rufulum, not clade IV as suggested in that study.

17a. Ascoma disc yellow-brown ... 18

17b. Ascoma disc orange to cinnabar-red .. 19

18a. Ascospores 27-34 × 7-12 $\mu \mathrm{m}$, about 3-4 times as long as broad; ascomata rather stout, up to $1.8 \mathrm{~mm}$ long and $1.3 \mathrm{~mm}$ broad; ascospores reddish brown; type: Thailand R. neorufulum Thambug. \& K.D. Hyde (Thambugala, et al., 2016)

18b. Ascospores $19-31 \times 8-13 \mu \mathrm{m}$, about 2-3 times as long as broad; ascomata elongate, up to $3.4 \mathrm{~mm}$ long and 0.7 mm broad; ascospores dark brown; type: Thailand

R. tectonae Doilom \& K.D. Hyde (Doilom, et al., 2016)

19a. Ascoma disc cinnabar-red; ascospores 19-25 $\times$ 7.5-11.5 $\mu \mathrm{m}$; type: India ............ R. quercinum (B.G. Desai \& V.N. Pathak) M.P. Sharma \& Rawla (Desai \& Pathak, 1970; Sharma \& Rawla, 1986)

19b. Ascoma disc orange; ascospores 28-37 × 9-14 $\mu \mathrm{m}$; material: Costa Rica .......... R. clade I (Murillo, et al., 2009)

Notes. This clade likely represents an undescribed species.

\section{Acknowledgements}

The workshop and field trip during which the material was collected was organized as part of the annual symposium of the The Grupo Colombiano de Liquenología (GCOL). The participation of the second author in this even was supported by a grant from the National Science Foundation: Neotropical Epiphytic Microlichens - An Innovative Inventory of a Highly Diverse yet Little Known Group of Symbiotic Organisms (DEB 0715660 to The Field Museum; PI R. Lücking). The Universidad del Valle provided logistic support for the workshop and field trip.

\section{Conflict of interests}

The authors declare no conflict of interest.

\section{References}

Almeida, D. A. C., Gusmão, L. F. P. \& Miller, A. N. (2014) Brazilian Semi-Arid Ascomycetes I: New and interesting records of hysteriaceous ascomycetes. Mycosphere. 5: 379-391.

Álvarez, L. M., Piñeros, Z., Restrepo, C., Restrepo, J. H. \& Velasco, E. (1987) Propuesta para la protección del bosque de San Antonio. Centro de Datos para la Conservación CDC - CVC.

Anahosur, K.H. (1971; '1970') Ascomycetes of Coorg (India) II. Sydowia. 24: 177-182.

Barr, M. E. (1990) Some dictyosporous genera and species of Pleosporales in North America. Memoirs of the New York Botanical Garden. 62: 1-92.

Batista, A. C. \& Maia, H. da S. (1964; '1963') Diversos Ascomycetes da Amazônia. Anais do Congresso Nacional da Sociedade Botânica do Brasil. 14: 133-156.

Bezerra, J. L. \& Kimbrough, J. W. (1979; '1978') A new species of Tremella on Rhytidhysterium rufulum. Canadian Journal of Botany. 56: 3021-3033.

Boehm, E. W.A., Mugambi, G. K., Miller, A. N., Huhndorf, S. M., Marincowitz, S., Spatafora, J. W. \& Schoch, C. L. (2009) A molecular phylogenetic reappraisal of the Hysteriaceae, Mytilinidiaceae and Gloniaceae (Pleosporomycetidae, Dothideomycetes) with keys to world species. Studies in Mycology. 64: 49-83.

Brown, J. G. (1953) A new species of Hysterographium. Mycologia. 45: 964-967.

Chander, J., Singla, N., Kundu, R., Handa, U. \& Chowdhary, A. (2016) Phaeohyphomycosis caused by Rhytidhysteron rufulum and review of literature. Mycopathologia. i...:? 1-5.

Chaparro, D. F., Rosas, D. C. \& Varela, A. (2009) Isolation of wood-decaying fungi and evaluation of their enzymatic activity (Quindio, Colombia)]. Revista Iberoamericana de Micologia. 26: 238-243.

Chokpaiboon, S., Choodej, S., Boonyuen, N., Teerawatananond, T. \& Pudhom, K. (2016) Highly oxygenated chromones from mangrove-derived endophytic fungus Rhytidhysteron rufulum. Phytochemistry. 122: 172-177.

Chowdhary, A., Guarro, J., Randhawa, H. S., Gené, J., Cano, J., Jain, R. K., Kumar, S. \& Khanna, G. (2008) A rare case of chromoblastomycosis in a renal transplant recipient caused by a non-sporulating species of Rhytidhysteron. Medical Mycology. 46: 163-166. 
Cooke, M. C. \& Ellis, J. B. (1877) New Jersey fungi. Grevillea 5: 30-35, 49-55, 89-95.

Desai, B. G. \& Pathak, V. N. (1970) A new Tryblidiella from India. Sydowia. 24: 198-200.

Doilom, M., Dissanayake, A. J., Wanasinghe, D. N., Boonmee, S., Liu, J. K., Bhat, D. J., Taylor, J. E., Bahkali, A. H., McKenzie, E. H. C. \& Hyde, K. D. (2016) Microfungi on Tectona grandis (teak) in Northern Thailand. Fungal Diversity: DOI:10.1007/s13225-016-0368-7.

Ellis, J. B. (1889) Triblidium rufulum (Sprenzel). Journal of Mycology. 5: 29-30.

Ellis, J. B. \& Everhart, B. M. (1892) The North American Pyrenomycetes. A Contribution to Mycologic Botany. Newfield, New Jersey.

Hsieh, W. H., Chen, C. Y. \& Sivanesan, A. (1997) Some new ascomycetes from Taiwan. Mycological Research. 101: 897-907.

Karsten, P. (1866) Enumeratio Fungorum et Myxomycetum in Lapponia orientale aestate 1861 lectorum. Notiser ur Sällskapets pro Fauna et Flora Fennica Förhandlingar. 8: 193-224.

Kutorga, E. \& Hawksworth, D. L. (1997) A reassessment of the genera referred to the family Patellariaceae (Ascomycota). Systema Ascomycetum. 15: 1-110.

Magnes, M. (1997) Weltmonographie der Triblidiaceae. Bibliotheca Mycologica. 165: 1-177.

Mahajan, V. K., Sharma, V., Prabha, N., Thakur, K., Sharma, N. L., Rudramurthy, S. M., Chauhan, P. S., Mehta, K. S. \& Abhinav, C. (2014) A rare case of subcutaneous phaeohyphomycosis caused by a Rhytidhysteron species: a clinico-therapeutic experience. International Journal of Dermatology. 53: 1485-1489.

Méndez-Mayboca, F., Checa, J., Esqueda, M. \& Chacón, S. (2010) New records of Loculoascomycetes from natural protected areas in Sonora, Mexico. Mycotaxon. 111: 19-30.

Mishra, K., Das, S., Goyal, S., Gupta, C., Rai, G., Ansari, M. A., Saha, R. \& Singal, A. (2014) Subcutaneous mycoses caused by Rhytidhysteron species in an immunocompetent patient. Medical Mycology Case Reports. 5: 32-34.

Murillo, C., Albertazzi, F. J., Carranza, J., Lumbsch, H. T. \& Tamayo, G. (2009) Molecular data indicate that Rhytidhysteron rufulum (ascomycetes, Patellariales) in Costa Rica consists of four distinct lineages corroborated by morphological and chemical characters. Mycological Research. 113: 405-416.

Pande, A. (2008) Ascomycetes of Peninsular India. Jodhpur Scientific Publishers, India. 584 p.

Peck, C. H. (1894; ' 1893') Report of the Botanist (1892). Annual Report on the New York State Museum of Natural History. 46: $85-149$.

Pena, C. E. (1967) Deep mycotic infections in Colombia. A clinicopathologic study of 162 cases. American Journal of Clinical Pathology. 47: 505-520.

Penzig, A. J. O. \& Saccardo, P. A. (1897) Diagnoses fungorum novorum in insula Java collectorum. Ser. II. Malpighia. 11: 491-530.

Pudhom, K. \& Teerawatananond, T. (2014) Rhytidenones A-F, spirobisnaphthalenes from Rhytidhysteron sp. AS21B, an endophytic fungus. Journal of Natural Products. 77: 19621966.

Pudhom, K., Teerawatananond, T. \& Chookpaiboon, S. (2014) Spirobisnaphthalenes from the mangrove-derived fungus Rhytidhysteron sp. AS21B. Marine Drugs. 12: 1271-1280.
Restrepo, A. (1970) Paracoccidioidomycosis (South American blastomycosis). A study of 39 cases observed in Medellin, Colombia. American Journal of Tropical Medicine and Hygiene. 19: 68-76.

Rosatto, V. G. (1996) Revisión de los Géneros Patellaria Fr. y Rhytidhysteron Speg. (Fungi: Ascomycetes) y Géneros Afines de la República Argentina. Doctoral Dissertation, Facultad de Ciencias Naturales y Museo, Universidad Nacional de La Plata. 166 p.

Saccardo, P. A. \& Berlese, A. N. (1885) Fungi Australienses Miscellanea Mycologica. 2: 1-12.

Samuels, G. J. \& Müller, E. (1980; '1979') Life-history studies of Brazilian ascomycetes 7: Rhytidhysteron rufulum and the genus Eutryblidiella. Sydowia 32: 277-292.

Sharma, M. P. \& Rawla, G. S. (1986; '1985') Ascomycetes new to India - III. Nova Hedwigia. 42: 81-90.

Silva-Hanlin, D. M. \& Hanlin, R. T. (1999) Small subunit ribosomal RNA gene phylogeny of several loculoascomycetes and its taxonomic implications. Mycological Research. 103: 153-160.

Spatafora, J. W., Mitchell, T. G. \& Vilgalys, R. (1995) Analysis of genes coding for small-subunit rRNA sequences in studying phylogenetics of dematiaceous fungal pathogens. Journal of Clinical Microbiology. 33: 1322-1326.

Spegazzini, C. (1880) Fungi argentini. Pugillus primus. Anales de la Sociedad Científica Argentina. 9: 158-192.

Spegazzini, C. (1881) Fungi argentini additis nonnullis brasiliensibus montevideensibusque. Pugillus quartus (Continuacion). Anales de la Sociedad Científica Argentina. 12: 174-189.

Spegazzini, C. (1888) Fungi Guaranitici. Pugillus II. Anales de la Sociedad Científica Argentina. 26: 5-74.

Spegazzini, C. (1919; '1918') Reliquiae mycologicae tropicae. Boletín de la Academia Nacional de Ciencias en Córdoba. 23: $365-541$.

Spegazzini, C. (1921) Mycetes chilenses. Boletín de la Academia Nacional de Ciencias en Córdoba. 25: 1-124.

Sprengel, K. P. J. (1820) Plantarum cryptogamicarum tropicarum pugillus. Kongliga Svenska Vetenskaps-Akademiens Handlingar. 3 (8): 46-53.

Tanaka, K. \& Hosoya, T. (2006) Some new records of Loculoascomycetes from Yakushima Island, southern Japan. Bulletin of the National Science Museum, Series B (Botany). 32: $151-160$.

Thambugala, K. M., Hyde, K. D., Eungwanichayapant, P. D., Romero, A. I. \& Liu, Z. Y. (2016) Additions to the Genus Rhytidhysteron in Hysteriaceae. Cryptogamie Mycologie: 37: 99-116.

Vasco-Palacios, A. M. \& Franco-Molano, A. E. (2013) Diversity of Colombian macrofungi (Ascomycota-Basiciomycota). Mycotaxon. 121: 1-58.

Vega, F. E., Simpkins, A., Aime, M. C., Posada, F., Peterson, S. W., Rehner, S. A., Infante, F., Castillo, A. \& Arnold, A. E. (2010) Fungal endophyte diversity in coffee plants from Colombia, Hawai'i, Mexico and Puerto Rico. Fungal Ecology. 3: 122-138.

Wipf, P., Lynch, S., Birmingham, A., Tamayo, G., Jiménez, A., Campos, N. \& Powis, G. (2004) Natural product based inhibitors of the thioredoxin-thioredoxin reductase system. Organic and Biomolecular Chemistry. 2: 1651-1658.

Yacharoen, S., Tian, Q., Chomnunti, P., Boonmee, S., Chukeatirote, E., Bhat, J. D. \& Hyde, K. D. (2015) Patellariaceae revisited. Mycosphere. 6: 290-326. 